\title{
Spontaneous Resolution of Intra-Abdominal Cyst in a Fetus with Normal Karyotype
}

\author{
M. Murat Naki, Oluş Api, Hasniye Acıŏ̆lu, Müge Emeksiz, Aybala Akı1, Orhan Ünal \\ Dr. Lütfi Kırdar Kartal Eğitim ve Araştırma Hastanesi Kadın Hastalıklarn ve Doğum Anabilim Dal, İstanbul, Türkiye
}

\begin{abstract}
Objective: To report a case of an intraabdominal cyst of a 19 weeks' fetus which was diagnosed in a 25-year-old primigravida who was referred for routine ultrasonographic examination

Case: Bmode sonography revealed an anechoic, multilocular, septated cystic mass located lower right abdominal section, beneath the liver whereas color Doppler examination revealed no remarkable blood flow. The 23 weeks' scan showed that the cystic abdominal mass was spontaneously regressed.
\end{abstract}

Conclusion: We discuss the significance and differential diagnoses of the spontaneously regressed cyst in a fetus with normal karyotype.

Keywords: Intra-abdominal cyst, fetal ultrasound, spontaneous regression, normal karyotype.

\section{Normal karyotipli bir fetüste intra-abdominal kistik kitlenin spontan rezolüsyonu}

Amaç: Rutin ultrasonografik değerlendirme için başvuran 25 yaşında, primigravid bir gebenin 19 haftalık fetüsünde tanı alan bir intraabdominal kistik kitle olgusunu sunmak.

Olgu: 25 yaşında primigravid hasta, 19. gebelik haftasında rutin ultrasonografik inceleme için kliniğimize başvurmuştur. Ultrasonografik incelemede, sağ abdominal bölgede, karaciğer komşuluğunda yerleşmiş, düzenli sınırları olan, 32×39 mm boyutlarında anekoik, multiloküler, septalı kistik kitle saptanmıştır. Renkli Doppler incelemede lezyon içi kan akımında artış izlenmemiştir. Fetal büyüme ve amniotik sıvı indeksi normaldi. Hastanın isteği üzerine amniosentez yapılmış ve sonucu normal gelmiştir. Yirmiüçüncü haftada yapılan incelemede kistik abdominal kitlenin spontan olarak regrese olduğu görülmüştür. Doğum anına kadar rekürrens saptanmamıştır. Otuzsekizinci haftada sezaryenle canlı kız bebek doğurtulmuştur. Bebeğin doğum sonrası abdominal ultrasonografik incelemesinde patolojik bulgu saptanmamıştır. Bmod ultrasonografide (USG) sağ alt abdominal bölgede, karaciğerin altında yerleşim gösteren, Renkli Doppler USG'de belirgin kan akımı izlenmeyen, anekoik, multiloküler, septalı kistik kitle bulunmuştur. Yirmi üçüncü hafta USG'sinde kistik abdominal kitlenin spontan regrese olduğu görülmüştür.

Sonuç: Burada, normal karyotipe sahip fetüste spontan regresyon gösteren kistin önemini ve ayırıcı tanılarını tartıştık.

Anahtar Sözcükler: Intra-abdominal kist, fetal ultrasonografi, spontan regresyon, normal karyotip.

\section{Introduction}

Fetal intra-abdominal cystic lesions, though not common, are increasingly referred for evaluation since the advent of routine antenatal ultrasonography. They may arise virtually from any abdominal organ; however, the urogenital and gastrointestinal systems are the ones most commonly involved. We report a spontaneously regressed intra-abdominal cyst in a fetus with normal karyotype.

\section{Case Report}

25-year-old primigravida was referred for routine ultrasonographic examination at 19 weeks of gestation. Ultrasonographic examination showed 
an anechoic, multilocular, septated cystic mass with regular margins measuring $32 \times 39 \mathrm{~mm}$, located lower right abdominal section, beneath the liver (Figure 1). The intralesional blood flow was unremarkable on Color Doppler (Figure 2). Fetal growth and amniotic fluid index remained normal. Upon patient's request, amniocentesis was performed which revealed normal karyotype. The 23 weeks' scan showed that the cystic abdominal mass was spontaneously regressed. No recurrence was detected until delivery. A normal female infant was delivered via cesarean section at 38 weeks'. No pathology found upon abdominal ultrasonographic evaluation of the neonate.

\section{Discussion}

There is only one reported similar case in the literature. ${ }^{[1]}$ Merenda et al. reported an abdominal anechoic fetal cyst showing multilocular septations with regular margins located close to the wall of lower right section of the abdomen at 24 weeks'. The cystic abdominal mass was found to be spontaneously regressed at 26 weeks' scan. However, this patient had a history of spontaneously regressed cystic hygroma between 9 and 12 weeks' gestation, and chorion villous sampling revealed a normal karyotype. No intra-abdominal pathology was found on postnatal magnetic resonance imaging. The authors proposed that the cystic mass might represent a fetal lymphatic anomaly. The differential diagnosis of an intra-abdominal cystic lesion in the fetus includes ovarian cyst, enteric

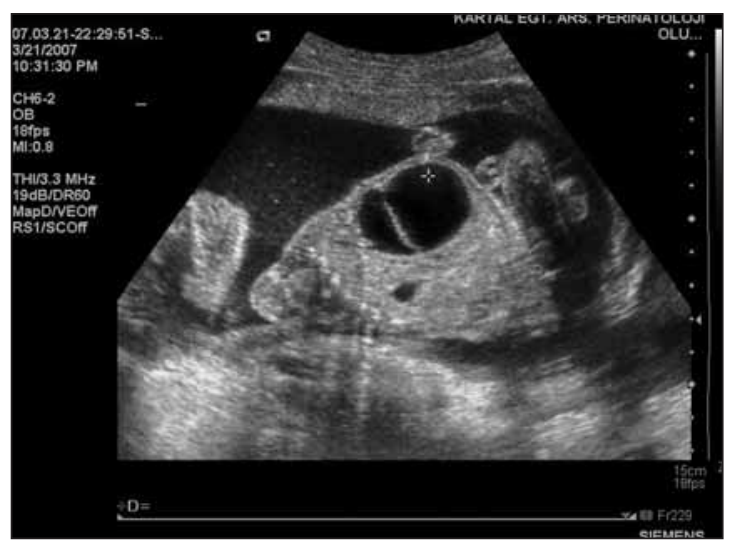

Figure 1. Septated cystic mass. duplication cysts, mesenteric cysts (abdominal lymphatic malformations), meconium pseudocysts and choledochal cysts. ${ }^{[2]}$ Among these, only ovarian cysts are known to show spontaneous resolution and have the best prognosis. ${ }^{[3,4]}$ They are mostly seen after 23 weeks' of pregnancy and the earliest case was reported at 19 weeks. ${ }^{[5]}$ Although the fetal gender was female in our case, it did not provide the characteristics of an ovarian cyst. Due to the abovementioned ultrasound characteristics, the lesion was thought to be either a mesenteric cyst or an enteric duplication cyst. Since no double wall sign was detected, the most probable diagnosis was considered to be a mesenteric cyst which is an abdominal lymphatic malformation. On ultrasound, the lesion is typically a large, well-circumscribed cystic structure with thin walls and usually contains multiple thin septae..$^{[7]}$ The prognosis is usually good but it may result in intestinal obstruction, or rarely, the cyst may rupture on neonate, and they usually require a postnatal surgical intervention $^{[8]}$ However, no case of a continuously regress mesenteric cyst has been reported up to date. Since we do not have pathologic confirmation of our data, it is hard to reach a definitive diagnosis.

\section{Conclusion}

In conclusion, based on our findings, our case might represent a transient lymphatic anomaly which was presented as a spontaneously regressing fetal intra-abdominal cystic mass.

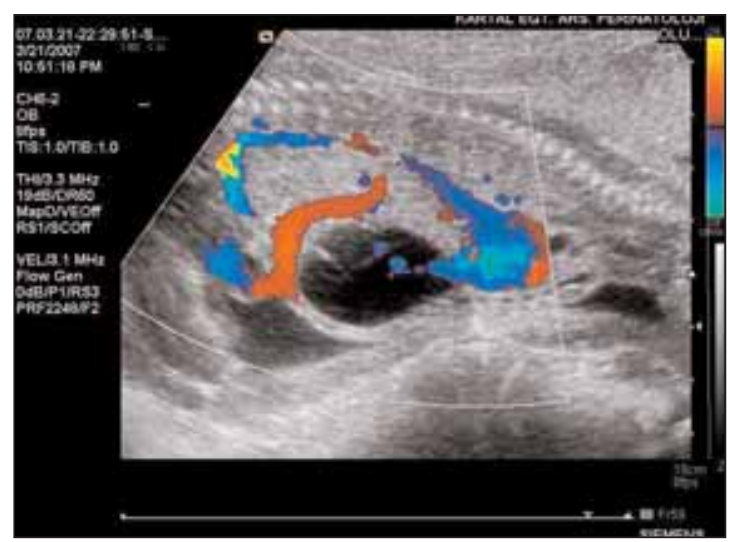

Figure 2. Color Doppler of cystic mass. 


\section{References}

1. Merenda A, Pisaturo ML, Laviscio P, Poppiti R, Nazzaro G. Spontaneous resolution of cystic hygroma colli and intraabdominal cyst in a fetus with normal karyotype. Ultrasound Obstet Gynecol 2008;32:398-446.

2. Khong PL, Cheung SC, Leong LL, Ooi CG. Ultrasonography of intra-abdominal cystic lesions in the newborn. Clin Radiol 2003;58:449-54.

3. Crombleholme TM, Craigo SD, Garmel S, D'Alton ME. Fetal ovarian cyst decompression to prevent torsion. J Pediatr Surg 1997;32:1447-9.

4. Giorlandino C, Rivosecchi M, Bilancioni E, Bagolan E, Zaccara A, Taramanni C, Vizzone A. Successful intrauterine therapy of a large fetal ovarian cyst. Prenat Diagn 1990;10:473-5.

5. Meizner I, Levy A, Katz M, Maresh AJ, Glezerman M. Fetal ovarian cysts: prenatal ultrasonographic detection and postnatal evaluation and treatment. Am J Obstet Gynecol 1991;164:874-8.

6. Konen O, Rathaus V, Dlugy E, Freud E, Kessler A, Shapiro M, Horev G. Childhood abdominal cystic lymphangioma. Pediatr Radiol 2002;32:88-94.

7. Lin JI, Fisher J, Caty MG. Newborn intraabdominal cystic lymphatic malformations. Semin Pediatr Surg 2000; 9:141-5. 